\title{
Digitalization of Social Protection Systems Policy in Indonesia as a Step Towards Society 5.0
}

\author{
Muhammad Aditya Purnomo \\ Department of International Relations \\ Airlangga University \\ Surabaya, Indonesia \\ adityapurnomo216@gmail.com
}

\begin{abstract}
Society 5.0 refers to recently announced Japan's vision towards a super smart society. It advances industrial-centered digital transformation from Industry 4.0, towards an all-encompassing human-centered development. One of Society 5.0's demands is that people lives securely, with strengthened government's safety nets against social issues such as poverty. Poverty remains a global challenge to be tackled in Sustainable Development Goals Agenda 2030, and previous literatures argued that Social Protection System is one of the core ingredients in poverty reduction. Indonesia has been applauded for successful reduction of its national poverty rate by half in past 20 years. While Indonesia also has an ambitious vision of near-zero poverty by 2045 , World Bank warned that the issue of coverage of the country's social protection system remains a challenge, especially if the system is to be future-ready. Social protection system in Indonesia has played an important role in delivering social assistances to poor households in the past two decades. Literature of digital transformation in Indonesia's social protection policy is still limited, therefore, this research serves to fill the gap as well as providing general ideas for future research. Utilizing the theories of digital government, digital social protection system, and Society 5.0 as theoretical framework, this research discusses the digitalization of Indonesia's Social Protection System and its possible contributions towards Society 5.0's demand of safeguarding against poverty. This research argues that digitalization of social protection system is an important step towards achieving society 5.0 in terms of strengthening government's social welfare policy based on two main reasons: It enhances government's coverage in delivering social benefits towards society via data utilization to tackle poverty as a social challenge, and it serves as a form of government automation which integrates physical and cyber space in social benefits delivery to safeguard social welfare against future possible shocks.
\end{abstract}

Keywords-Digitalization, Indonesia, Social Protection System, Society 5.0

\section{INTRODUCTION}

Society 5.0 is a vision of fourth development stage of humankind, which has been transformed from hunting, agrarian, industrial, and information. Japan recently announced the vision as an "Imagination Society", which is enabled by digital transformation that allows people to better pursue their dreams as well as contributing to global development agenda. However, in order to pursue such challenges with peace of mind, there is a need to safeguarded people against social issues such as poverty. Keidanren (Japan Business Federation) labelled such issues as "anxiety". One of the demands in Society 5.0 is that people must be "liberated" from the anxiety and be able to live securely through a strengthened safety nets against unemployment and poverty [1].

In the context of global development, poverty remains the first goal to be tackled in global development agenda Sustainable Development Goals 2030. International efforts have been long since placing the goal in the top list of United Nations Development Goals. Although the previous global agenda, Millennium Development Goals, has succeeded in reducing extreme poverty by half, the number remains high. One of key ingredients in poverty alleviation strategy is the implementation of Social Protection System [2].

Indonesia is one example of a country in which its social protection has played important role in reducing the national poverty rate by half in the last two decades. In 2000-2019, the number has decreased from 19.1 per cent to 9.2 per cent. World Bank has not only applauded the country's social protection system for playing key role in the achievement, but also warned that the issue of coverage remains a challenge for the system, especially if it is to be future-ready. Satu Kahkonen, World Bank's head representative for Indonesia and 
Timor-Leste, stated that the system's coverage needs to be strengthened in order to face growing challenges such as the growing populations and informal workforces. Indonesia is also facing a risk of incomplete coverage and insufficient benefits delivery of social protection, especially to elderlies and people with disabilities. In addition, the country also has an ambitious vision of Indonesia 2045 where Government of Indonesia (GoI) aimed to achieve near-zero poverty. Modern and future-ready social protection programmes is needed by Indonesia to face continuous changes. Kahkonen added that there is no better time than present to think and improve the social protection in Indonesia [3].

Previous studies have discussed about Indonesia's social protection system policy. During 1997 Asian Financial Crisis, GoI's cash transfer program has become 'catalyst of change' which serves as a basis for the country's subsequent social protection policies. The initially emergency-measure-against-crisis program was seen by policy makers as crucial policy instrument, which not only gained policy importance in Indonesia's politics, but also initiated the development of institutional structure for social protection system implementation [4]. Also, GoI needs to pay increased attentions in key elements, such as the systems' coverage, quality, additional benefits i.e. unemployment, maternity etc., as well as cooperation and coordination between intra-governmental ministries, trade unions, and workers. Lawenforcement is also important to prevent cheating among beneficiaries [5]. In addition, the implementation of Indonesia's social protection programmes is still "haunted" by the issue of misstargeting such as some cases where the vulnerable poor are excluded from the programs because they are residing in urban areas, while some of the non-poor are included instead. There is a need for policy-makers to address targeting effectiveness of the programmes in decision-making processes to accurately achieve their implementation goals [6]. Another problem in Indonesia's social protection is, although since Sistem Jaminan Sosial Nasional (National System of Social Insurance; SJSN) Law No.40 Year 2004 was enacted social protection has made great progress, some aspects such as workplace protection, death insurance, and pensions for the elderlies hasn't progressed much. A study indicated that Indonesia's social protection system tend to only protect civil servants, armed and police forces, and wealthy citizens [7], which indicates similar findings to [6] that there is a need to address the miss-targeting issue between the poor and non-poor. There is also a need for GoI to develop a unified social protection system because the current system tends to be fragmented and overlapped, which lead to possible inefficiencies. GoI not only needs to carefully plan the programmes to target appropriate beneficiaries and avoiding further overlaps, but also needs to develop a database of social protection that consists of important information such as the sex and poverty status of potential beneficiaries to facilitate program delivery [8]. A study suggests that, although not being specific on social protection system, the utilization of data or big data is potentially advantageous in Indonesia's public sector policy. The data can be used by policy-makers to formulate data-analysis-based decisions in public sector such as health and education sector, and ensuring food security. The study also stated that the use of data as source of information and knowledge development in policy-making process is vital in the era of Society 5.0 [9].

Studies presented above show that there is an urgency to discuss how Social Protection System in Indonesia has to move forward, tackling the abovementioned problems, while also preparing for the upcoming Society 5.0.

This study aims to discuss the answer to the urgency. The author argues that digitalization of social protection system is an important step towards achieving society 5.0 in terms of strengthening government's social welfare policy based on two main reasons: It enhances government's coverage in delivering social benefits towards society via data utilization to tackle poverty as a social challenge, and it serves as a form of government automation which integrates physical and cyber space in social benefits delivery to safeguard social welfare against future possible shocks.

\section{THEORETICAL FRAMEWORKS}

\section{A. Digitalizing Social Protection Systems}

Social Protection refers to set of policies and programs aimed to reduce poverty and vulnerabilities. It comprises of social insurances (such as insurance for elderlies and people with disabilities, and pensions), social assistances (such as non-contributory health insurance, unconditional cash transfers, conditional cash transfers, child protection), and labour market program, which are all designed to enhance target citizen's capacity to protect themselves against loss of income [8]. Social Protection Systems is stated in Sustainable Development Goals (SDGs) 2030 agenda indicator 1.3. "Implement nationally appropriate social protection systems and measures for all, including floors, and by 2030 achieve substantial coverage of the poor and the vulnerable" [10]. Prior to 1997 Asian economic crisis, social protection was seen as marginal in the context of development. The idea of "giving free cash transfer to those who don't work" was considered an expensive method and was argued to worsen the culture of poverty. During 1980s economic liberalization, World Bank argued that safety nets are acceptable only as reserve for the poorest or socially vulnerable populations. However, during 1997 Asian economic crisis, World Bank realized the program's importance and promoted it as a key component in poverty reduction strategies. International Labour Organization (ILO) led the early years of global 
campaign to promote the importance of social protection system [11].

According to ILO's World Social Protection Report 2017-2019, extending social protection system's coverage and adapting it to new forms of work and employment are important in reducing vulnerabilities and insecurity especially for those who are previously excluded. In terms of healthcare, social protection system contributes to effort of achieving universal health coverage, including access to essential healthcare services, medicines, and vaccines for all. In terms of old-age pensions, the objective is to achieve universal social protection for all older persons. For children and family, the services are delivered in forms of cash benefits, childcares, child educations (until certain levels), social security for parents in term of employment, etc. In short, increased efforts to achieve universal social protection, where its range and benefits meet population needs, is necessary to accomplish the objectives of Sustainable Development Goals Agenda 2030 [12].

In social protection systems delivery, digital infrastructures play important roles in multiple aspects, such as information delivery to potential beneficiaries, involving them in ongoing assistance programs, identify and screen their eligibility, making payments, and following up to disputes and complaints. There is a term 'digital trinity' in digital infrastructure value chain which comprises of three important factors. They are digital ID systems, mobile communications, and digital payment systems which in general fulfil the roles mentioned above. Countries worldwide had invested in developing their digital infrastructures which include creation of nation-wide ID systems, spread of mobile networks, and making digital payments available not only for commercial and person-to-person transfers but also social transfers. In Brazil, there is Cadastro Union, a social register utilized to serve the country's social programs. In Pakistan, there is National SocioEconomic Registry (NSER) which plays similar role to Cadastro Union by covering a wide range of households. In Turkey, a national ID number can be linked across a range of databases in order to specifically categorize potential beneficiaries into specific criteria [13].

Digital trinity is argued to play important role in delivering social protection in circumstances where physical interactions are limited, such as the current Covid-19 pandemic where lockdown initiatives are being widely implemented. The utilization of registers or databases of social protection beneficiaries and the communication and integration between the databases and pandemic response programmes, are the critical ways in which technology has shaped Covid-19 responses. In short, it is important to data-integrate between digital trinity and government's programmes. In terms of social programmes' payments mechanisms, there has been a growing trend in many countries to shift from physical cash distributions to digital payments in responding to Covid-19 crisis. In India, national ID system Aadhar has aided in bank account transfer to 200 million women. In Togo, there is Novissi program which utilizes mobile money payment mechanism to beneficiaries especially those in 'lockdown' areas [13]. In general, the emergence of current Covid-19 pandemic has intensified the utilization of digital measures in social protections [14].

\section{B. Digital Government in Public Welfare Delivery}

"Digital Government" in general refers to government's utilization of information and communication technologies (ICT) or other digital tools to deliver public services. Government also uses governmental database to automatically deliver the services while minimizing active bureaucracy and participations. The emergence of digital governments is to combat exclusions in service delivery. The exclusions are caused by physical environments and physical interactions, such as long waiting lines and phenomena of citizens' applicant discriminations by the bureaucrats. The transition to digital systems provides new types of bureaucracy, namely screen-level bureaucracy and system-level bureaucracy. The former still maintains citizen-bureaucracy interaction but with increased use of computer screens and internet connections, while the latter fully utilizes digital systems programmed to execute public policy [15]. There is a concept of Digital Welfare, which is specific to the digitalization in the areas of health, social, education, and protection services, that involves smarter use of technologies [16]. Governments around the globe are increasingly expected to modernize public sector delivery especially in areas mentioned above, labelled by Organisation for Economic Co-operation and Development (OECD) as high impact areas. Digital transformation in those areas will play key role in increasing service effectiveness and satisfaction, as well as trust, openness, and engagement with the governments [17].

An example of government automation is Norway's child benefit policy. The country's most expansive and universal policy has been automated since 1998. The automation mechanism is applied starting from the registration process. The computer systems of the welfare organization are automatically triggered when the data of a recently born child (or children) is entered into national database. The system automatically checks the registry to determine if the mother is eligible for the benefits. Afterward, the benefit-claims are generated in the case handling system. The entirelyautomated mechanisms, including informing the beneficiaries of their accepted applications as well as the payment processes, are regularly and frequently reviewed by the assigned caseworkers. Citizens are also able to apply through manual mechanisms, in which they need to fill online forms and upload needed documentation to government webpages [15]. 
OECD mentioned three main strands as the objectives of digital welfare policies, i.e. efficiency, effectiveness, and good governance. Efficiency is stated to be the key driver of digital transformation in public sector. The digitalisation not only reduces costs, especially in administrative procedures and labour, but also improves citizen's experience to government's welfare services. Effectiveness refers to decisions that utilizes technology to enhance policy outcomes. Good governance refers to policy objectives that put accountability, transparency, and citizen's engagement and trust in government as important policy objectives [17]. The use of data, known as Big Data, therefore serves as a "weapon" as well as a "challenge" for government in integrating it with public services delivery [9]. OECD's Digital Government Policy Framework 2020 stated that a data-driven public sector governs data as key strategic asset not only in planning, but also in delivering and monitoring public policies. There are several important points in what OECD calls a "truly data-driven government". First, government recognises and governs data as a key strategic asset while also defines its values, measures its impacts as well as actively remove any barriers to data management, data-sharing, and data-reuse. Second, the government applies data to transform the design, the delivery, and monitoring of public policies and services. Third, there is a need to openly publish data and make use of it within public sector organisations. Finally, government needs to understand citizen's right of data especially in terms of ethical behaviours, transparency of usage, and protecting their privacy and data security. In addition, government also needs to rely less on survey-based analytics and rely more on datadriven analytics. It is beneficial for the government in terms of demographic analysis, opinions, needs, etc., of its citizens. In the end, it is important for government to be proactive in interacting with the public, especially when digital tools and technologies have become important part of government functions and service delivery [18].

\section{Society 5.0 demand of Digital Transformation}

Cabinet Office (CAO) Japan defines Society 5.0 as a human-centered society which put economic advancement and resolution of social problems in balance through the utilization of a system with high degree of convergence between cyber and physical space. In Society 5.0, information is collected from what CAO refers as sensors in physical space. The information, accumulated in cyberspace by a huge amount resulting in big data, then analysed and returned back to physical space in various form. The technologies such as internet, big data, even robotics and Artificial Intelligence (AI), continue to progress and affect the course of society. Japan, as the initiator of Society 5.0, seeks to incorporate these technologies not only in industries but also in social activities to achieve both economic development and solving social problems [19].
The development of human society has always been based on the principles of liberation from restrictions through utilizing new tools and techniques which give births to enhanced capabilities. Humans have moved a long way from Hunting Society 1.0, to Agrarian Society 2.0, Industrial Society 3.0, and Information Society 4.0. In short, humans have lived through hunting, agrarian, industrial, and information. In order to breakthrough onto the next level of society, the key demand is the digital transformation [1]

Keidanren Japan emphasized the meaning of digital transformation as advances in digital technology and data utilization that drastically change many aspects of society including private lives, public administrations, industrial structures, and employment. The use of data will facilitate visualization of issues and possible solutions, which then leads to resolution of social issues. One of data-based technologies is the Internet of Things (IoT). Keidanren specified that in IoT, every "thing" is internet-connected, which enables precise data-collections from physical world, our society, to be deployed into cyberspace as digital data [1].

Digital transformation through data utilization will strengthen government's public services including the social safety nets. Government's effort in strengthening the country's social safety nets is aligned with one of Society 5.0's premises of liberation, i.e. "People will be liberated from anxiety and live in security. Specifically, resilience against terrorism and disasters in physical spaces and attacks in cyberspace will be enhanced, and safety nets for unemployment and poverty will be strengthened" [1]. Report on The $5^{\text {th }}$ Science and Technology Basic Plan, in which CAO Japan presented their ideas of Society 5.0, stated that systems in various fields will be able to coordinate and collaborate thus widening their range of automation and autonomy by leveraging ICT to its maximum potential. CAO proposed that such utilization of ICT will then merge physical space and cyberspace, resulting in their proposed ideal form of future society that they refer as "super smart society". The society is characterized by the fulfilment of its different needs by providing necessary products and services in the required amount for people who need them, and delivered in the needed time. People are expected to live a comfortable and vigorous life, fulfilled of their allowances regardless of age, sex, region, and language [20].

\section{DISCUSSIONS}

\section{A. The Development of Social Protection Database in Indonesia}

Social protection system in Indonesia in general is divided into contributory and government-financed non-contributory scheme for the poor. In the latter category, there are various social assistance programmes. In terms of food assistance programmes, there are Rastra and Bantuan Pangan Non Tunai (NonCash Food Assistance; BPNT). In terms of conditional 
cash transfers, there is Program Keluarga Harapan (Family Hope Programme; PKH). For cash transfers specific to child education for the poor, there is Program Indonesia Pintar (Indonesia Smart Programme; PIP). In terms of fully subsidized national health insurance, there is Jaminan Kesehatan Nasional - Penerima Bantuan Iuran (JKN-PBI). Indonesia invests 0.73 per cent of Gross Domestic Product (GDP) to its social protection system, with 0.55 per cent of GDP being invested to the non-contributory schemes [21].

Efforts to digitalize social protection system in Indonesia have started since 2005, during which Gol started to develop Basis Data Terpadu untuk Program Penanggulangan Kemiskinan (Unified Database for Poverty Alleviation Programmes), an electronic-based database which contains social, economic, demographic information. The development of the database marked the first step in establishing information architecture for the country's social protection system aimed to scale up social assistance implementations. The data needed for the database were collected through a statistic survey Pendataan Sosial Ekonomi (Socioeconomic Data Collection) which was started in the same year. The survey included information from approximately 19 million poor households in the bottom 30 per cent of income distribution. The database was used as a foundation for the implementation of various social protection programmes, such as Rastra, PKH, PIP, etc. [22]. The implementation of PKH in 2007 marked the beginning of data utilization in Indonesia's social protection system. The pilot stage started in 7 provinces in Indonesia. It initially targeted 500,000 households categorized as Rumah Tangga Sangat Miskin (Very Poor Household; RTSM). The database then was updated regularly once every three years through further survey called Pendataan Program Perlindungan Sosial (Social Protection Program Data Collection; PPLS) which was conducted in 2008 and 2011. In both 2005 and 2008 survey, data collected were limited to RTSM, Rumah Tangga Miskin (Poor Households; RTM), and Rumah Tangga Hampir Miskin (Near-poor Households; RTHM categories. In 2011, those categories were merged into Rumah Tangga Sasaran (Target Households; RTS), which consists of 40 per cent of overall middle-lower households. The management of the data collected is the responsibility of government body Tim Nasional Percepatan Penanggulangan Kemiskinan (National Team of Poverty Alleviation Acceleration; TNP2K). The team also ranked the data through Proxy Means Tests (PMT). The data then integrated into a database called Basis Data Terpadu (BDT). The utilization of BDT in delivering social protection programmes started in 2012-2014 [23].

In 2015, PPLS survey changed its name into Pemutakhiran Basis Data Terpadu (Renewal of Unified Database; PBDT). One of the mechanisms made available by PBDT is the establishment of Forum Konsultasi Publik (Public Consultation Forum; FKP), in which the purpose is to increase the accuracy of data collected through 2011 PPLS survey. The result of 2015 PBDT then was assigned to Indonesia's Ministry of Social Affairs through Pusat Data dan Informasi Kesejahteraan Sosial (Center of Data and Information of Social Welfare; PusdatinKesos), and in 2016 the ministry began responsible for the data management [23].

In 2017, GoI began the development of Sistem Informasi Kesejahteraan Sosial Next Generation (Information System of Social Welfare Next Generation; SIKS-NG), which is an application-based management of Data Terpadu. The data then was nicknamed Data Program Penanganan Fakir Miskin dan Orang tidak Mampu (Program Data of Extreme Poor and People Incapable of Fulfilling their Daily Needs; DT-PPFM and OTM). The application also began to integrate with various social protection programmes such as PKH, Rastra, and BPNT. The update of DT-PPFM and OTM was held between once and thrice a year in 2017-2019. In 2019, Data Terpadu changed its name into Data Terpadu Kesejahteraan Sosial (Unified Data of Social Welfare; DTKS), which increased its data inclusion not only limited to the data of extreme poor, but also other social-welfare-related data such as data of Bantuan Sosial (Social Assistances), data of Pemerlu Pelayanan Kesejahteraan Sosial (People in needs of Social Welfare Services; PPKS), and data of Potensi dan Sumber Kesejahteraan Sosial (Potential and Source of Social Welfare; PSKS). There was also an increase in DTKS update frequency from 2 times to 4 times a year. The responsibilities of data validation and verification were then decentralized to sub-national governments [23]. In data collecting activities, data collection staffs are able to utilize SIKS-NG android smartphone application known as SIKS-droid to input the collected data from regular household visits including household identities, coordinates, and housing conditions without needing conventional paper-based data inputs [24].

In 2019, according to president decree Peraturan Presiden nomor 39 tahun 2019 tentang Satu Data Indonesia, all policies must be made based on data [25]. According to the decree, GoI's Satu Data Indonesia policy refers to data management policy which aimed to produce data that is accurate, updated, unified, accountable, and available for share-use between central government and regional government. The decree also stated that the policy serves as a basis to support the planning, implementation, evaluation and control of development projects [26].

\section{B. Government Data Utilization to Enhance Social Protection Coverage}

This section discusses GoI's capability of data utilization in enhancing social protection coverage. In GoI's medium-term development plan 2015-2019 
document, in order to support government's social protection development, GoI stated that there is a need for a basis data for planning within a unified information system which serves as a forum of information exchange between central and regional governments [27]. The statement was further strengthened by president Jokowi's decree in 2019 Peraturan Presiden Nomor 39 Tahun 2019 tentang Satu Data Indonesia. The decree was intended by GoI to better regulate Indonesia's data management. According to the decree, there are several principles that serve as basis: 1) Data produced by Produsen Data (Data Producer) must adhere to Standar Data (Data Standards); 2) Data produced by Produsen Data must have Metadata; 3) Data produced by Produsen Data must adhere to rules of Interoperabilitas Data (Data Interoperability); 4) Data produced by Produsen Data must utilize Kode Referensi (Refence Codes) and/or Data Induk. [28]. The decree stated the concept, definition, classification, size, and units of Standar Data. As a concept, Standar Data refers to the idea that serves as a basis of which the data is produced. As a definition, it refers to the boundaries of the data which explicitly set it apart in from other data in terms of meaning and coverage. In terms of classification, Standar Data refers to systematic categorization of data into groups or categories based on criteria determined by Pembina Data (Data Admin). In terms of size, it refers to units used in calculating amounts or coverage. Finally, in terms of unit, Standar Data refers to specific scale in data that is/are used as standard(s) of measurement as a whole. The decree also stated that the policy of Satu Data Indonesia serves as a basis to support the planning, implementation, evaluation, and control of development projects. From policy-level, the policy showed that GoI has determined to standardize data utilization for better data management. In addition, the decree also stated GoI's objective in making the data available for share-use among intra-governments [26]. GoI has coordinated its inter-ministries to integrate with the decree. In September 2020, Pusdatin Kesos conducted Sosialisasi Kebijakan Satu Data Indonesia within Ministry of Social Affairs. Mirza Pahlevi, head of Pusdatin Kesos of Indonesia Ministry of Social Affairs, stated that the event was intended to align perceptions regarding Satu Data Indonesia, and to conduct socialization about Walidata (a central government division that would be responsible for data collection, checking, and management) and Produsen Data. The event also serves as a response to the Peraturan Presiden Nomor 39 Tahun 2019 tentang Satu Data Indonesia [29].

In 2019, the development of GoI's database for social protections has reached the establishment of DTKS database. The database is integrated into the implementation of Indonesia's social protection programme such as PKH. According to Indonesia's Ministry of Social Affair's data, GoI has significantly increased both Cakupan (coverage) and Anggaran (budget) of PKH since its implementation in 2007. In
2018, the coverage reached 10 million Keluarga Penerima Manfaat (beneficiaries households; KPM), which shows significant increase from only $500 \mathrm{KPMs}$ in 2007. In 2018 the annual budget exceeded Rp 17 billion compared to Rp 0.39 billion in 2007 [30].

According to research conducted by TNP2k and SMERU Indonesia, DTKS is not only used for the implementation of $\mathrm{PKH}$, but also for other social protection programmes such as PIS for healthcare benefits, PIP for education, Program Sembako for staple foods, and other subsidies such as electricity bills and other needs. Therefore, PKH beneficiaries are all eligible to receive the abovementioned programmes [31].

DTKS is also used to determine eligibility for elderlies age 70 above to receive social protection programmes. Elderlies are usually registered into $\mathrm{PKH}$. However, in 2019 GoI has implemented a rehabilitation programmes for elderlies called Program Rehabilitasi Sosial Lanjut Usia (Social Rehabilitation Program for Elderly; Progres $L U$ ) that has been developed and evolved since 2006. The program in general is aimed to recover and develop the elderlies' social function. However, those eligible for Progres $L U$ must not be registered in $\mathrm{PKH}$. Eligibility for Progres $L U$ is determined by GoI's Ministry of Social Affairs using DTKS. The amount of cash transferred in 2019 is Rp $2,400,000$ annually or Rp 200,000 monthly. In 2020 , the amount increased to $\operatorname{Rp} 2,700,000$ annually. However, in assisting against Covid-19 pandemic, the amount was further increased to $\mathrm{Rp} 3,000,000$ annually since April 2020. In national scale, the coverage of social protection programmes for elderlies has been significant. According to the data provided in the research, social insurance coverage for elderlies in national scale reached 83.9 per cent for top 20 per cent economic group, 70.7 per cent for the middle 40 per cent, and 65.8 per cent for bottom 40 per cent economic group. However, GoI's progress of elderlies' social protection coverage seems to be more focused on social insurances rather than social assistances. In some cities such as Jakarta and Bali, the difference of coverage between social insurance and social assistance were more than double the ratio i.e. 89-94 per cent social insurances coverage and 2-57 per cent coverage for social assistances. However, the differences were much wider for higher economic groups in most cases presented in the research. TNP2k stated through the document that GoI is currently more focused on delivering social protection to lower economic groups [31].

In general, the establishment of DTKS database in 2019 has enhanced the country's social protection system delivery. Indonesia Ministry of Social Affairs in August 2020 stated that DTKS, that was managed by Pusdatin Kesos of Indonesia Ministry of Social Affairs, has enhanced citizen enrolments in social protection system in both national and municipal-households. 
According to the ministry's data, there is an increase of coverage in multiple non-contributory social protection programmes. PKH coverage has increased from 30 to 31 per cent in 2018-2019. PIP coverage has increased from 22 to 23 per cent, and Program Indonesia Sehat (Indonesia Healthy Programme; PIS) coverage went up from 56 to 60 per cent during the same period. There is also a coverage increase for beneficiaries enrolled in multiple programmes. PKH-PIP combined coverage has increased from 12 to 15 per cent, PKH-Rastra increased from 24 to 25 per cent, and PKH-PIP-Rastra went up from 10 to 13 per cent during the period. The ministry also stated that by utilizing DTKS as database, Indonesia's social protection policies and programmes become more efficient and effective in efforts of reducing expenditure burden of the poor [32].

Expanding the coverage of Indonesia's social protection system is important especially in efforts of reducing poverty. World Bank estimated that by doing so, the three indicators including poverty, vulnerability, and inequality rate will be reduced. According to projections in [3], focusing on coverage expansion in addition to merging multiple social protection programmes such as merging PIP with $\mathrm{PKH}$, pose better potency of the three indicator reductions compared to merging alone. Merging PIP with PKH for example, is estimated to reduce poverty rate by 4 per cent and vulnerability rate by 1 per cent. However, in addition to the merging scenario, expanding $\mathrm{PKH}$ coverage to 40 per cent will potentially reduce poverty rate by 31 per cent, vulnerability rate by 9 per cent, and inequality Gini ratio by 1.3. If those scenarios are to be added with expanding elderlies' social assistances coverage to 70 per cent, the three indicators are estimated to be reduced by 41 and 12 per cent, and 1.8 respectively [3].

There is also a need to expand the coverage specific to categories of people with disabilities (PWD). In Indonesia, PWDs are facing challenges of access to health, education, labour market, and social protection. According to TNP2K's document of Disability Situation Analysis: Challenges and Barriers for People with Disability in Indonesia, PWD category amounts up to 9 per cent of total population. Also, proportion of PWD specific to age groups of 60 years and above are significantly greater than the proportion to other age groups. From the total population of 23,301,517 PWD, 41.9 per cent are elderlies. This sparks the need to further enhance social protection coverage, not only for general population, but also for elderlies and PWD [33].

Social protection system for PWD is covered in PIP for education, and Jaminan Kesehatan Nasional Penerima Bantuan Iuran (National Health Insurance Program; JKN-PBI) for non-contributory health insurance scheme. In PIP, GoI still needs to pay increased attention regarding PWD's access to the programme. For children aged 7-18, the proportion of those registered in PIP is only as low as 11 per cent from national PWD population of 780,558. In the case of bottom 40 per cent economic group, the number of children registered in PIP is only slightly higher of 16 per cent which shows that from the total of 338,406 children in bottom 40 per cent economic group (2019 figures), 281,395 are not receiving PIP. Better access to PIP is highly needed in the current situation. In addition, better access to PIP is also needed to improve PWD's level of graduation. Currently, only 32 per cent proportion of PWD's national population own graduation certificate up to senior secondary school level, and only 28 per cent of PWD's bottom 40 per cent economic group achieved the same level. The low rate of PWD access to PIP may impede GoI's goal in achieving universal access to education. In JKN-PBI, PWD's rate of access to the programme is higher compared to PIP i.e. 38.1 per cent of national population, and 46.2 per cent of bottom 40 per cent economic group population. However, the numbers also show that from the total of more than 23 million PWD in national population and over 9 million in bottom 40 per cent economic group, there are still more than half of them that are not registered in the insurance scheme [33].

Society 5.0 requires people to be freed from anxiety of social issues such as poverty. Enhancing government coverage in delivering social protection system is important to safeguard citizen against such anxiety. In the case of Indonesia, the government needs to put increased attention in enhancing social protection system coverage not only to general population, but also to elderlies and PWD. It is as stated in CAO's proposal of "super smart society" that people's needs, including products and services, must be provided in the required amount, and delivered in the needed time, without discriminating various indicators such as age and sex. The view is aligned with GoI's objective stated in the country's medium term development plan Rencana Pembangunan Jangka Menengah Nasional (RPJMN) 2015-2019. In section 6.3.3 of the document under the term "Penanggulangan Kemiskinan" (Poverty Alleviation), GoI stated that social protection is needed to fulfil the needs of the poor especially health and staple foods, as well as protecting them in times of economic or social shocks. GoI also stated that there is a need to increase the coverage of basic services including law, education, health, basic infrastructures, and inclusive economies for the poor including people with disabilities and elderlies [27].

In establishing the connection between the current situation and the fulfilment of needs in Society 5.0, there are several points that need to be addressed. First, the "super smart society" requires that people's need must be provided in the required amount. In the case of social protection coverage in general as presented in [32], the increase of coverage due to the utilization of DTKS shows that GoI is on its way to achieve the requirement of providing people's needs. However, in order to achieve what CAO Japan stated as the 'required 
amount', further effort to increase the coverage is necessary. By assuming that the 'required amount' refers to universal social protection coverage not limited or discriminated to poor or non-poor, means that a significantly higher coverage percentage is necessary for Indonesia to cover the national population as a whole. Currently, DTKS serves as the main weapon in national targeting of Indonesia's social protection system. However, there is a need to further enhance the database in order to better pursue Society 5.0. TNP2k also sees that while the database has played important role in delivering the country's social protection, it needs further strengthening especially in the management of target determination. The current DTKS, as of TNP2k's published policy brief in August 2020 , only managed to contain data of 38 per cent of Indonesia's population. Compared to other developing countries, Indonesia's DTKS put the country in middleposition in terms of social registry scope of coverage, on par with Brazil's Cadastra Unico. The coverage is still significantly lower than Pakistan's NSER, Rep. Dominica's SIUBEN, and Philippines' Listahanan that are placed in top three covering 87 per cent, 85 per cent, and 75 per cent of their national populations respectively. Also, even though it was stated that DTKS managed to cover 38 per cent of national population, the number doesn't reflect the database's coverage of the country's social protection programmes as a whole. Statistics provided in the policy brief shows that there are only some programmes that managed to reach almost 40 per cent coverage, such as JKN-PBI and other programmes such as electricity subsidy [34]. The situation shows that in case of programmes with lower coverage percentages, the fulfilment of people's needs especially for those relying on the programmes to support their livelihoods might be impeded.

Second, society 5.0 requires people to be freed from anxiety of social issues such as poverty. Indonesia has successfully reduced its national poverty rate to 9.2 percent of population in 2019 compared to 19.1 per cent in 2000. However, the emergence of Covid-19 pandemic will potentially threaten the achievement [3]. According to Indonesia's Badan Pusat Statistik (Center of Statistics; BPS), the national poverty rate has increased from 9.22 per cent in September 2019 to 10.19 in September 2020 [35]. It indicates that from the total population of 270 million according to 2020 BPS Census [36], there are as many as 27 million Indonesians still living in poverty. The number will potentially increase as Covid-19 pandemic continues. TNP2k added that the 'gap' in DTKS coverage needs to be addressed especially in lessening the impact of Covid-19. GoI has invested Rp 110 billion in delivering Jaring Pengaman Sosial (Social Safety Nets; JPS), in which DTKS must play important role as a robust targeting system. However, there are still several problems that could potentially undermine the coverage of not only the current anti-Covid-19-JPS, but also the country's social protection programmes as a whole. First, DTKS still largely consists the data from PBDT
2015 survey. TNP2k stated that during the span between that year and the current socioeconomic condition of Indonesian households, there has been substantial changes that needs to be updated into the database. Second, as proposed by TNP2k, there is a need to strengthen DTKS utilization by improving the Sistem Penetapan Sasaran Nasional (National Target Determining System; SPSN). Not only GoI needs to introduce a regulation to better manage SPSN especially in terms of its accuracy, time, and system administration, but also needs to establish an interministry steering committee to guide the framework in strengthening SPSN [34]. In the current situation, there is no certain expected period or duration in which Covid-19 pandemic may continue. Although the national poverty rate has been in constant decrease in 2000-2019 which shows that Indonesia had been close in freeing its citizen from the anxiety of poverty, the arrival of Covid-19 pandemic posed a serious threat to the two-decades-long achievement. Therefore, this section concludes that although DTKS has enhanced Indonesia's social protection delivery, GoI needs to further strengthen it in order to liberate its citizen from the anxiety of poverty as social issue, especially in the current Covid-19 pandemic.

\section{Integrating Physical and Cyberspace Convergence in Social Protection System}

Society 5.0 requires the utilization of a system that converges physical space and cyber space. CAO Japan stated that information collected by 'physical sensors' in physical space will be accumulated in cyberspace and then returned back to physical space in various form. In social activities, such convergence is utilized to solve social problems [19].

Indonesia's past social protection system in dealing with past economic crisis such as the 1997 Asian Financial Crisis is characterized by sole use of physical space. Jaring Pengaman Sosial, a social safety net against the crisis, functions as a direct cash transfer from central government to villages (or equivalents). In general, the delivery of Indonesia's social protection since 1997-2016 was still dominated by physical method, in which the cash transferred from government are mostly received by lembaga penyalur (governmentassigned social protection benefit distributors) before distributed directly to beneficiaries. TNP2k's policy paper Modernisasi Government to Person (G2P) melalui Solusi Financial Technology (Fintech) di Indonesia stated that in the delivery of $\mathrm{PKH}$, such mechanism requires long verification procedures which increases potential of corruption and miss-targeting of beneficiaries. In 2016, under President Jokowi and Vice President Jusuf Kalla administration, GoI set 4 (four) objectives in poverty alleviation strategies: 1) Repair the country's social protection programmes; 2) Increase access to basic services; 3 ) Productivity Training of the Poor; 4) Achieve inclusive development. More specific, GoI developed Strategi Nasional Keuangan Inklusif (National Strategy of Inclusive Monetary; SNKI) 
through president decree Peraturan Presiden nomor 82 tahun 2016. GoI aimed to widen the coverage of access to formal monetary services especially for the poor by transforming government-to-person social protection payment from cash-based to cashless mechanisms, including the use of mobile money, NFC, ATM debit cards, and fingerprint and face biometrics [37].

In 2012-2014, TNP2k in coordination with Oxford Policy Management Ltd., analyzed the payment system of social protection program, especially in PKH. They tried to identify the effectivity of trial mechanism of electronic payment. The payment involves the use of Giro Pos and bank account TabunganKu in coordination with state-owned bank Bank Rakyat Indonesia (BRI). TNP2k found that, while the use of TabunganKu showed several problems such as limited bank network especially in rural areas and low rate of possessions of mobile bank accounts, such ATMtransfer-based payments or e-wallets are regarded by TNP2k as potentially advantageous for social protection delivery as it simplifies benefit claims. In addition, TNP2k found that there is a need to involve non-bank participation in providing assistances to government in cash benefits distribution to beneficiaries. In 2014, the recently elected President Jokowi initiated the implementation of Program Simpanan Keluarga Sejahtera (PSKS), along with PIP and PIS. In PSKS, GoI in coordination with stateowned postal company Pos Indonesia distributed mobile phone SIM cards to approximately 1 million poor households. The cards contain e-money in form of saving accounts set by GoI as part of cashless mechanism. In the same year, TNP2k involved Bank Mandiri in continuing the trial mechanism. It utilizes mobile-phone-based Mandiri E-Cash as method of delivery to 1.300 beneficiary households in cities of North Jakarta, Cirebon, and Kupang. It was found that while there were still notable problems such as cash transfer failures and network problems, mobile-phonebased payments provide quick registration and benefits delivery procedures as well as high transaction security. In 2015 , TNP2k in coordination with state-owned cellular company Telkomsel conducted trial mechanism of distributing electronic voucher to three cities/equivalents i.e. Central Jakarta, Cirebon, and Semarang. The vouchers, which were distributed twice in December 2015 and January 2016, contained Rp 100.000 that were intended by GoI to be used by each beneficiary to pay for primary needs such as rice, electricity, and gas. The vouchers were distributed to 2,029 households using T-Cash, a Near Field Communication (NFC) technology developed by Telkomsel. Upon registering, beneficiaries were given stickers of T-Cash NFC that will be used in benefits claim. Beneficiaries then were informed regarding the schedule of their benefits claim. They need to bring their national ID cards and sticker-imbued mobile phones to stations assigned by Telkomsel. TNP2K stated that in addition to the advantages of being costfree and user-friendly, the trial also showed that beneficiaries prefer cashless mechanisms to traditional mechanisms of benefits delivery. In 2016, TNP2k, in coordination with Badan Perencanaan Pembangunan Nasional (Government Body of National Development; Bappenas) and GoI ministry of social affairs, continued another trial mechanism involving multiple banks such as BRI, Bank Negara Indonesia (BNI), Bank Pembangunan Daerah Jawa Tengah (BPD Jateng), and BTPN alongside with Telkomsel. In 2019, TNP2k coordinated with Tim Pengendali Penyelenggaraan Bantuan Sosial Nontunai (Team of the Implementation of Cashless Social Assistance) to conduct three different test mechanisms in delivering cashless social protection payments. First is by utilizing face biometrics and fingerprints mechanisms in coordination with BRI and Everest. Second is by utilizing e-voucher and Short Message Service (SMS) mechanisms in coordination with BNI and VOX company. Third is through the utilization of $e-K T P$ (electronic national ID) and fingerprints in cooperation with Bank Mandiri. The three trial mechanisms, as stated by TNP2K, showed that the time needed in benefits delivery is only as short as 2-5 minutes in addition to the registration processes that took 10-15 minutes. In addition, the success rate of such mechanisms is as high as $82-84$ per cent. Failures were usually caused by technical problems such as signal coverage and identity data inputs mistakes. TNP2k concluded that cashless benefits delivery utilizing face biometrics is favourable because it is easy to operate, cost-friendly, and secure [37].

GoI has mandated that Social Protection benefits delivery needs to be cashless. In 2017, through president decree Peraturan Presiden Republik Indonesia Nomor 63 tahun 2017, GoI stated that cashless social protection delivery is aimed to increase efficiency in order to be received by citizen right on time, quantity, and quality. The decree stated that the delivery will utilize Bank Penyalur (Banks of benefits deliveries), Kartu Kombo (Combo Cards) that functions as both electronic money card and savings card, and Elektronik Warung Gotong Royong or also known as EWarong (Government-assigned agents, merchants, and/or others that coordinate with Bank Penyalur to function as stations of benefits delivery for beneficiaries) [38].

TNP2 $\mathrm{k}$ is currently on progress in developing the implementation model of delivering cashless benefits. In the model, GoI utilizes G2P (Government to Person) server as a database storing beneficiaries' identities. The identities were transferred from the main government database Adminduk Dukcapil that consists of Nomor Induk Kependudukan (National ID Number; NIK) and other administrative data. The model is aimed to support the implementation of face biometric mechanism in benefits claim. TNP2k stated that face biometric technology will be crucial in establishing an electronic-based benefits delivery. Beneficiaries will utilize face biometric through their mobile phones to 
authenticate benefits claim from the assigned merchant. Data collected from the authentication will then be send to G2P server along with phone number and bank account data. The information then will be archived in order to enhance the database. In the future, TNP2k recommended GoI to integrate the database with DTKS which consists of social protection beneficiaries' data [37].

In establishing the connection between the current situation of Indonesia's social protection benefit claim and Society 5.0's demand of physical-cyberspace convergence, GoI's attempt in developing the cashless social protection payment mechanisms serves as an attempt in establishing a government automation that merge physical and cyberspace. One example of such automation is, in the case of public policy, is the fully automated benefits claim of Norway's child benefit policy. In the policy, the benefit claim mechanism is fully automated by the system from the moment a data is registered, to automatic eligibility check within national registry, to benefit-claim that is automatically generated through the case-handling systems [15]. In the example, sensors in physical space indicated by data input of recently born child or children sent the information to the cyberspace. The data then accumulated in cyberspace in forms of national registry which enables eligibility checks before transferred back into physical space in forms of benefit claim (or rejection if they did not meet eligibility criteria). In the current situation of Indonesia's social protection benefit claim, such degree of automation has not yet fully reached. In PIP for example, beneficiaries must first make a formal letter signed by school (or equivalents) headmasters indicating that the individual is going to claim cash benefit from the programme. The letter then serves as one required document along with copies of student report, Kartu Tanda Penduduk (national ID card; KTP), Kartu Keluarga (Family register) that must all be brought to Lembaga Penyalur in order to claim the cash benefit in forms of direct cash payment [39].

Developing a government automation in social protection benefits delivery by utilizing physicalcyberspace integration, is important to shield population from future possible $\operatorname{shock}(\mathrm{s})$. The integration is an important step not only in dealing with possible future circumstances during which physical interactions may be limited like the current Covid-19 pandemic, but also an important proponent for Society 5.0 in which, by utilizing digital transformation, people must be liberated from anxiety of social issues such as poverty. Satu Kahkonen, World Bank country director for Indonesia and Timor Leste, stated that as Covid-19 pandemic is likely to increase vulnerabilities to poverty, countries that have already established social registries covering majority of population are able to respond rapidly and comprehensively as well as protecting households from livelihood shocks. Shielding population against shocks is important. According to World Bank's report Social Protection for Indonesia's
2045 Vision, Indonesia has encountered various disasters since 2004, which caused from US\$ 0,4 to 2,3 billion in financial damage from each disaster encountered. Annual reported economic impact of natural disasters in 2000-2016 was approximately US\$ 1.4 billion. In addition, the report found that World Risk Index has ranked Indonesia among the highest level of exposure to natural hazard-related risks [3].

During the current Covid-19 pandemic, social protection that utilizes cashless payment mechanism will be an advantage. Because in the future, there might be possibilities of shock(s) with similar circumstances in which physical interactions are limited. Countries around the world has begun to develop and implement digital-based social protection benefits delivery in combating the current pandemic. Some examples of developing countries utilizing such method are Pakistan, India, South Africa, etc. Countries with stronger integration between national ID or registries with digital mechanisms in benefits delivery will, in general, be able to implement their social protection programmes more rapidly compared than those with weaker integration [13]. Pakistan, for example, has implemented full-biometric payment mechanism Ehsaas Emergency Cash (EEC) in response to Covid19 pandemic. The mechanism is integrated with the country's NSER national unified database that covers approximately 85 per cent of population. In 2020, EEC has been delivered to about 87 per cent of those enrolled [40].

Indonesia's attempt in developing cashless social protection payment mechanism has shown that the country tried to place itself among those with stronger capability to respond against shock(s). While the system is still under development and some ideas are still being proposed, such as the establishment of G2P Server and Adminduk Dukcapil as databases of cashless payment, GoI has slowly moved from what Larrson cited as "screen-level bureaucracy", to "system-level bureaucracy". The former is shown in the provided example of PIP, in which the country still utilizes the combination of citizen interaction with computer screens and internet connection. In the latter, Indonesia has begun utilizing an increased use of technologies i.e. the G2P server and Adminduk Dukcapil database in determining beneficiaries' eligibility, while at the same time decreasing physical requirement such as the need to bring many documents and visiting required places to obtain signature from appointed officers. This section concludes by stating that while currently Indonesia has not been able to fully integrate physical and cyberspace in social protection payment delivery, the country is on its way to develop such integration in order to be advantageous in safeguarding its citizen against future possible shock(s).

\section{CONCLUSIONS}

The current situation of social protection system in Indonesia shows that the country is still far from 
achieving Society 5.0 in which humans' need are fulfilled in the required amount, and people are liberated from the anxiety of poverty. The arrival of Covid-19 pandemic threatened the country's twodecades-achievement of constant poverty reduction, especially when the social protection system needs further strengthening in order to enhance its coverage. However, the pandemic also showed that there is a need to develop a mechanism in which limited physical interactions will not be a problem. Future possible shock(s) may come without any warning, such as the sudden arrival of current pandemic, and the circumstances of how social protection systems will be delivered will also varies. Better coverage and heightened convergence between physical and cyberspace will not only make Indonesia one step closer to achieving Society 5.0, but also make the country readier to safeguard its citizen against future possible $\operatorname{shock}(\mathrm{s})$.

\section{REFERENCES}

[1] Keidanren, Society 5.0: Co-creating the Future (Excerpt) Keidanren, 2018. Accessed on April 24, 2021. [Online]. Available:

https://www.keidanren.or.jp/en/policy/2018/095_proposal.pdf

[2] M. Kaltenborn, "Overcoming extreme poverty by socia protection floors - approaches to closing the right to socia security gap," Law and Development Review, vol. 10, no. 2, pp. 237-273, 2017. Accessed on April. 24, 2021. [Online]. Available doi: 10.1515/ldr-2017-0014

[3] C. Holmemo, et al., Investing in People: Social Protection for Indonesia's 2045 Vision. Jakarta: World Bank Indonesia, April 2020. Accessed on April. 25, 2021. [Online]. Available: https://openknowledge.worldbank.org/bitstream/handle/10986 133767/AUS0001352.pdf?sequence=4\&isAllowed=y.

[4] H. Kwon and W.Kim, "The evolution of cash transfers in Indonesia: policy transfer and national adaptation," Asia \& the Pacific Policy Studies, vol. 2, no. 2, pp. 425-440, 2015 Accessed on April. 25, 2021. [Online]. Available doi: 10.1002/app5.83.

[5] T.T.H. Tambunan and B. Purwoko, "Social protection in Indonesia," in Social protection in Southeast \& East Asia, E. Adam, Ed. Singapore: Friedrich Ebert Stiftung, 2002, pp. 21 73. Accessed on April 25, 2021. [Online]. Available: http://library.fes.de/pdf-files/iez/01443003.pdf.

[6] A.S. Kusumawati and T. Kudo, "The effectiveness of targeting social transfer programs in Indonesia," The Indonesian Journal of Development Planning, vol. III, no. 3, pp. 282-297, December. 2019. Accessed on April. 25, 2021. [Online]. Available https://doi.org/10.36574/jpp.v3i3.90

[7] M. Widjaja and R.A. Simanjuntak, "Social protection in Indonesia: How far have we reached?," in Social Protection in East Asia - Current State and Challenges. ERIA Research Project Report, M.G. Asher, S. Oum, and F. Parulian, Eds. Jakarta: ERIA, 2010, pp. 157-181. Accessed on April. 25, 2021. [Online]. Available: https://www.eria.org/uploads/media/Research-ProjectReport/RPR_FY2009_9_Chapter_6.pdf.

[8] S.M. Adioetomo, E.L. Pardede, Q. Quarina, "Republic of Indonesia: Updating and improving the social protection index (cofinanced by the Republic of Korea e-Asia and Knowledge Partnership Fund)," Technical Assistance Consultant's Report Project Number: 44152 Regional — Capacity Development Technical Assistance (R-CDTA). Asian Development Bank, August 2012. Accessed on April. 25, 2021. [Online].
Available: https://www.adb.org/sites/default/files/projectdocument/76086/44152-012-reg-tacr-33.pdf.

[9] F. Rahmanto, U. Pribadi, A. Priyanto, "Big data: What are the implications for public sector Policy in society 5.0 era?," IOP Conf. Series: Earth and Environmental Science, vol. 717, pp. 1-7, 2021. Accessed on April. 25, 2021. [Online]. Available doi:10.1088/1755-1315/717/1/012009.

[10] United Nations, Global Indicator Framework for the Sustainable Development Goals and Targets of the 2030 Agenda for Sustainable Development, United Nations, 2021. Accessed on April 30, 2021. [Online] Available: https://unstats.un.org/sdgs/indicators/Global\%20Indicator\%20 Framework\%20after\%202021\%20refinement_Eng.pdf021.

[11] F. Merrien, "Social protection as development policy: A new international agenda for action," International Development Policy, Articles and Debates 4.2, 2013. Accessed April. 28, 2021. [Online]. Available https://doi.org/10.4000/poldev.1525.

[12] International Labour Organization (ILO), World Social Protection Report 2017-19: Universal Social Protection to achieve the Sustainable Development Goals. Geneva: International Labour Office, 2017. Accessed on April. 30, 2021. [Online]. Available: https://www.ilo.org/wcmsp5/groups/public/---dgreports/--dcomm/---publ/documents/publication/wcms_604882.pdf.

[13] A. Gelb and A. Mukherjee, "Digital technology in social assistance transfers for Covid-19 relief: Lesson from selected cases," CGD Policy Paper 181. Washington DC: Center for Global Development, September 2020. Accessed on May. 5, 2021. [Online]. Available: https://www.cgdev.org/sites/default/files/digital-technologysocial-assistance-transfers-covid-19-relief-lessons-selectedcases.pdf.

[14] S. Masiero, "Covid-19: What does it mean for digital social protection?," Big Data \& Society, July-December, pp. 1-6, 2020. Accessed on April. 25, 2021. [Online]. http://dx.doi.org/10.1177/2053951720978995.

[15] K.K. Larsson, "Digitization or equality: When government automation covers some, but not all citizens," Government Information Quarterly, vol. 38, no. 1, January 2021. Accessed on May. 1, 2021. [Online]. Available https://doi.org/10.1016/j.giq.2020.101547.

[16] A. Larsson and R. Teigland, "An introduction to digital welfare: A way forward?," in Digital Transformation and Public Services: Societal Impacts in Sweden and Beyond, A. Larsson and R. Teigland, Eds. London: Routledge, 2019, pp. 1-11. Accessed on May. 5, 2021. [Online]. Available doi: $10.4324 / 9780429319297-1$.

[17] OECD, "Digital government strategies for transforming public services in the welfare areas," OECD Comparative Study. OECD, 2016. Accessed on May 2, 2021. [Online]. Available: https://www.oecd.org/gov/digital-government/DigitalGovernment-Strategies-Welfare-Service.

[18] OECD, "The OECD government policy framework: Six dimensions of a digital government," OECD Public Governance Policy Papers No. 02. OECD, 2020. Accessed on May 2, 2021. [Online]. Available: https://dx.doi.org/10.1787/f64fed2a-en.

[19] Cabinet Office (CAO), Society 5.0, CAO, n.d. Accessed on April 28, 2021. [Online]. Available: https://www8.cao.go.jp/cstp/english/society5_0/index.html.

[20] Cabinet Office Government of Japan, Report on The $5^{\text {th }}$ Science and Technology Basic Plan, Cabinet Office Government of Japan, December 18, 2015. Accessed on May 2, 2021. [Online]. Available: https://www8.cao.go.jp/cstp/kihonkeikaku/5basicplan_en.pdf.

[21] The National Team for the Acceleration of Poverty Reduction (TNP2K), The Future of the Social Protection System in Indonesia: Social Protection for All. Jakarta, 2018. Accessed on May. 12, 2021. [Online]. Available: 
http://tnp2k.go.id/download/6083200829\%20TNP2K\%20Soc ial\%20Protection\%20for\%20All\%20Exec\%20Summary_EN G.pdf.

[22] OECD, "Social protection system review of Indonesia," OECD Development Pathways. Paris: OECD Publishings, 2019 Accessed on May 2, 2021. [Online]. Available: https://doi.org/10.1787/788e9d71-en.

[23] Kementrian Sosial RI, Sejarah DTKS, Kementrian Sosial RI, 2020. Accessed on April 28, 2021. [Online]. Available: https://dtks.kemensos.go.id/sejarah-data-terpadukesejahteraan-sosial-dtks.

[24] Kementrian Sosial RI, SIKS-NG, Kementrian Sosial RI, 2020. Accessed on April 25, 2021. [Online]. Available: https://dtks.kemensos.go.id/Profil\%20DTKS/topic/333.

[25] S.M. Pahlevi, et al., Reformasi Pengelolaan Data Terpadu Kesejahteraan Sosial. Jakarta: Pusat Data dan Informasi Kesejahteraan Sosial Kementrian Sosial Republik Indonesia, 2021. Accessed on June. 22, 2021. [Online]. Available: https://dtks.kemensos.go.id/uploads/topics/16151310721228. pdf

[26] Presiden Republik Indonesia, Peraturan Presiden Republik Indonesia Nomor 39 Tahun 2019 Tentang Satu Data Indonesia, Sekretariat Kabinet RI, 2019. Accessed on April 25, 2021. [Online]. Available: https://jdih.setkab.go.id/PUUdoc/175860/Perpres_Nomor_39 _Tahun_2019.pdf.

[27] Presiden Republik Indonesia, Peraturan Presiden Republik Indonesia Nomor 2 Tahun 2015 Tentang Rencana Pembangunan Jangka Menengah Nasional (RPJMN) 2015 2019: Indonesia yang Berdaulat, Mandiri dan Berkepribadian Berlandaskan Gotong Royong, Badan Perencanaan Pembangunan Nasional, 2014. Accessed on April 26, 2021. [Online]. Available: https://www.bappenas.go.id/files/rpjmn/RPJMN\%2020152019.zip.

[28] Kementrian Komunikasi dan Informatika Republik Indonesia, Jaga Akurasi dan Keterpaduan Data, Ini Kebijakan Pemerintah!, Kementrian Komunikasi dan Informatika Republik Indonesia, June 27 2019. Accessed on April 25, 2021. [Online]. Available: https://www.kominfo.go.id/content/detail/19531/jaga-akurasidan-keterpaduan-data-ini-kebijakan-pemerintah/0/berita.

[29] Kementrian Sosial RI, Sosialisasi Kebijakan Satu Data Indonesia (SDI), Kementrian Sosial RI, September 182020. Accessed on June 22, 2021. [Online]. Available: https://dtks.kemensos.go.id/sosialisasi-kebijakan-satu-dataindonesia-sdi.

[30] Kementrian Sosial RI, Program Keluarga Harapan (PKH), Kementrian Sosial RI, 2018. Accessed on June 22, 2021. [Online]. Available: https://dtks.kemensos.go.id/ar/programkeluarga-harapan-pkh.

[31] The National Team For The Acceleration of Poverty Reduction and The SMERU Research Institute, The Situation of the Elderly in Indonesia and Access to Social Protection Programs: Secondary Data Analysis. Jakarta: TNP2K, November 2020. Accessed on June. 23, 2021. [Online]. Available: http://www.tnp2k.go.id/download/83338Elderly\%20Study\%2 0-\%20Secondary\%20Data\%20Analysis.pdf.

[32] Kementrian Sosial Republik Indonesia, DTKS dan Komplementaritas Program Perlindungan Sosial, Kementrian
Sosial Republik Indonesia, August 2020. Accessed on June 23, 2021. [Online]. Available: https://dtks.kemensos.go.id/uploads/topics/15995805057755. pdf.

[33] M. Siyaranamual and D. Larasati, Disability Situation Analysis, Challenges and Barriers for People with Disability in Indonesia. Jakarta: TNP2K, October 2020. Accessed on June. 25, 2021. [Online]. Available: http://www.tnp2k.go.id/download/39050Disability\%20Situati on\%20Analysis.pdf.

[34] P. Asmanto, T. Hidayat, G.I. Suryanto, and S.N.F. Dewi, Covid-19 Pandemic and the Momentum to Strengthen the National Targeting System. Jakarta: TNP2K Secretariat, 2020. Accessed on: June. 20, 2021. [Online]. Available: http://www.tnp2k.go.id/download/31269PB_Pandemi\%20CO VID-

$19 \% 20$ dan $\% 20$ Momentum\%20untuk\%20Memperkuat\%20Sis tem\%20Penetapan\%20Sasaran\%20Nasional\%20_\%20Englis h.pdf

[35] Badan Pusat Statistik (BPS), Berita Resmi Statistik, BPS, February 2021. Accessed on June 22, 2021. [Online]. Available:

https://www.bps.go.id/website/materi_ind/materiBrsInd20210215114827.pdf.

[36] Badan Pusat Statistik (BPS), Hasil Sensus Penduduk 2020, BPS, January 2021. Accessed on June 22, 2021. [Online]. Available:

https://www.bps.go.id/website/materi_ind/materiBrsInd20210121151046.pdf

[37] Tim Nasional Percepatan Penanggulangan Kemiskinan (TNP2K), Asosiasi Fintech Indonesia (AFTECH), and Lembaga Demografi Fakultas Ekonomi dan Bisnis Universitas Indonesia, Modernisasi Government to Person (G2P) Melalui Solusi Financial Technology (Fintech) di Indonesia. Jakarta: Tim Nasional Percepatan Penanggulangan Kemiskinan, November 2020. Accessed on June. 23, 2021. [Online]. Available:

http://www.tnp2k.go.id/download/92212Buku_Modernisasi\% 20G2P\%20Melalui\%20Solusi\%20Financial\%20Technology $\% 20$ di\%20Indonesia.pdf.

[38] Presiden Republik Indonesia, Peraturan Presiden Republik Indonesia Nomor 63 Tahun 2017 Tentang Penyaluran Bantuan Sosial Secara Non Tunai, Badan Pemeriksa Keuangan Republik Indonesia (BPK RI), 2017. Accessed on July 7, 2021. [Online]. Available: https://jdih.bpk.go.id/wpcontent/uploads/2017/08/Perpres-Nomor-63-Tahun-2017.pdf.

[39] Kementrian Pendidikan dan Kebudayaan Republik Indonesia, Infografis Program Indonesia Pintar 2016, Kementrian Pendidikan dan Kebudayaan Republik Indonesia, August 8 2016. Accessed on July 7, 2021. [Online]. Available: https://www.kemdikbud.go.id/main/blog/2016/08/infografisprogram-indonesia-pintar-2016

[40] Y. Markhof, "Pakistan's social protection response to the COVID-19 pandemic: The adequacy of Ehsaas Emergency Cash and the road ahead," Working Paper Number 188. Brasília: International Policy Centre for Inclusive Growth, 2020. Accessed on July. 6, 2021. [Online]. Available: http://ipcig.org/sites/default/files/pub/en/WP188_Pakistan_s_ social_protection_response_to_the_COVID_19.pdf. 